ANANDA COOMARASWAMY MEMORIAL ORATION - 2018

\title{
REMARKABLE PETROGRAPHIC FEATURES OF SRI LANKAN GRANULITES; WITH SPECIAL REGARD TO UNEXPECTED OCCURRENCE OF “FELSITE-NANOGRANITE INCLUSIONS” IN GARNET
}

\author{
YOSHIKUNI HIROI ${ }^{1,2}$ \\ ${ }^{1}$ Department of Earth Sciences, Chiba University, Chiba, Japan \\ ${ }^{2}$ National Institute of Polar Research, Tokyo, Japan \\ *Corresponding Author e-mail: yhiroi@kza.biglobe.ne.jp \\ (Received $31^{\text {st }}$ January 2020; accepted $06^{\text {th }}$ February 2020)
}

\begin{abstract}
Fine spherulitic intergrowths of quartz and feldspar in felsite inclusions (FIs) in garnet in five representative granulite-facies rocks from northern, central and southeastern parts of the Highland Complex (HC), Sri Lanka, are presented together with an experimentally reproduced spherulitic intergrowth of similar dimensions. FIs show characteristics indicative of unexpectedly rapid cooling after far-fromequilibrium crystallization of trapped partial melts formed during high-grade metamorphism, because granulite-facies rocks in continental collision orogens generally have been presumed to be cooled and exhumed slowly from the depths for more than millions of years. Sri Lanka is the key place to unravel the mystery of rapid cooling of huge granulite masses and relevant geological processes because of the most widespread but apparently restricted occurrence of FIs along the marginal part of the HC in addition to accumulated geological, geochemical, and geochronological data.
\end{abstract}

Keywords: spherulite, felsite-nanogranite inclusion, rapid cooling of granulite, continental collision orogen

\section{INTRODUCTION}

Sri Lanka extensively exposes high-grade regional metamorphic rocks, which show various notable features; (1) arrested charnockitization (e.g., Hansen et al., 1987; Hiroi et al., 1990; Yoshida and Santosh, 1994; Kehelpannala, 1999; Perchuk et al., 2000, and references therein), (2) high purity vein graphite deposits (e.g., Erdosh, 1970; Hapuarachchi, 1977; Dissanayake, 1986; Hewathilake et al, 2018 ; Touret et al., 2019, and references therein), (3) occurrence of ultrahigh-temperature (UHT) mineral assemblages such as sapphirine + quartz and orthopyroxene + sillimanite + quartz (e.g., Osanai, 1989; Hiroi et al., 1994, Kriegsman and Schumacher, 1999; Sajeev and Osanai, 2004; Dharmapriya et al., 2015; Osanai et al., 2016a, and references therein), and so on. I have carried out petrological study of them for more than thirty years and found such interesting features as follows; (1) occurrences of relict prograde kyanite and staurolite with or without sapphirine and spinel in khondalite and UHT pelitic granulites as well as retrograde andalusite in various rocks (e.g., Hiroi et al.,1987, 1990, 1994, unpublished data; Ogo et al., 1992), (2) occurrence of garnet preserving compositional growth zoning of major and trace elements in granulite-facies rocks (Hiroi et al., 1995, 1997a), (3) occurrence of $\mathrm{Fe}$-rich kornerupine in pegmatite (Grew et al., 1995), (4) partial replacement of cordierite by andalusite + carbonate + quartz aggregates and ilmenite by rutile + siderite as the result of local infiltration of $\mathrm{CO}_{2}$ (Hiroi et al., 1990; Ellis and Hiroi, 1997), (5) replacement of sillimanite and garnet by spinel + feldspar \pm corundum intergrowths in some deformed khondalites (graphitic garnet-sillimanite gneiss) (Hiroi et al., 1997b), (6) metasomatic cordierite formation after plagioclase (Hiroi et al., unpublished data), and so on.

In particular, the occurrence of felsic volcanic rock-like inclusions (felsite inclusions, FIs) in garnet in various granulites is remarkable (Hiroi et al., 2014) (Table 1 and Fig. 1). 
Table 1. List of samples containing felsite-nanogranite inclusions in garnet from Sri Lanka.

\begin{tabular}{|c|c|c|c|c|c|}
\hline $\begin{array}{l}\text { Locality } \\
\text { in Fig. } 1\end{array}$ & Sample number & Locality & Rock type & Dendrite/spherulite & $\begin{array}{l}\text { Notable } \\
\text { minerals in } \\
\text { FNI }\end{array}$ \\
\hline \multirow[t]{2}{*}{1} & $88112704 \mathrm{~A}$ & Habarana & pelitic migmatite & spherulite & \\
\hline & H89082301A & & pelitic migmatite & spherulite & \\
\hline 2 & $87 C 4 '-3-2$ & Dambulla & pelitic migmatite & & \\
\hline 3 & 88112602 & Matale & khondalite & spherulite & \\
\hline 4 & $88112501 \mathrm{~B}$ & Matale & pelitic migmatite & & \\
\hline 5 & Y85092909C & Kandy & pelitic migmatite & dendrite & \\
\hline 6 & Y85101511 & Digana & khondalite & dendrite, spherulite & And \\
\hline 7 & $88111503 A^{*}$ & Teldeniya & pelitic migmatite & dendrite, spherulite & \\
\hline 8 & YH10092802B & Narangalla & pelitic migmatite & dendrite, spherulite & \\
\hline 9 & 88120203B & Moholawa & pelitic migmatite & & \\
\hline 10 & H89081302A & Nalla & pelitic migmatite & & \\
\hline 11 & MK13101101A & Peradeniya & pelitic migmatite & & \\
\hline 12 & 04090101I & Ampitiya & khondalite & & \\
\hline \multirow[t]{11}{*}{13} & $88112901 \mathrm{~A}$ & Victoria & Grt-rich pelitic gneiss & spherulite & \\
\hline & $88112901 \mathrm{H}$ & Reservoir & Grt-rich pelitic gneiss & spherulite & \\
\hline & YH02121901 & west & khondalite & dendrite & \\
\hline & 04083103A, B & (Talatuoya & khondalite & spherulite & Sil \\
\hline & YH10092601 & east) & khondalite & & \\
\hline & YH10092602A & & basic granulite & & An, Ep \\
\hline & H89082201B & & basic granulite & & An \\
\hline & G89082202A & & khondalite & & \\
\hline & H89082204A & & khondalite & & \\
\hline & G89082204A & & Grt-rich pelitic gneiss & spherulite & \\
\hline & G89082204C & & intermediate granulite & dendrite & And, Sil, Gdd \\
\hline 14 & M88112606 & Karametiya & pelitic migmatite & dendrite & And \\
\hline 15 & H89082601B & Algama & pelitic migmatite & & \\
\hline 16 & Y85100105 & Wattappola & pelitic migmatite & spherulite & \\
\hline \multirow[t]{6}{*}{17} & $\begin{array}{l}\text { Dlpt-1* } \\
(=88112401 \mathrm{~A} \\
03080801)\end{array}$ & Delpitiya & UHT pelitic granulite & dendrite, spherulite & $\begin{array}{l}\text { And, Sil, Spr, } \\
\text { Spl, Opx, } \\
\text { Crd, Wag }\end{array}$ \\
\hline & 04083001B* & & UHT pelitic granulite & dendrite, spherulite & Opx \\
\hline & $04083001 \mathrm{E}$ & & UHT pelitic granulite & dendrite, spherulite & \\
\hline & 04083003D* & & UHT pelitic granulite & dendrite, spherulite & And, Crn \\
\hline & 04083005B & & UHT pelitic granulite & dendrite, spherulite & Opx, Crd \\
\hline & YH10092501A & & UHT pelitic granulite & dendrite, spherulite & \\
\hline 18 & 88112205 & Kumbalgamuwa & pelitic migmatite & & And \\
\hline 19 & 02121707C & Nayapana & $\begin{array}{l}\text { Grt-bearing } \\
\text { charnockite }\end{array}$ & spherulite & $\begin{array}{l}\text { And, Opx, } \\
\text { Crd, Hbl }\end{array}$ \\
\hline 20 & YH18091203C & Passara & intermediate granulite & spherulite & And \\
\hline 21 & YH02121603B & Bandarawela & intermediate granulite & spherulite & \\
\hline 22 & YH18091305A & Koslanda & basic garnulite & & An, Ep \\
\hline 23 & Y85111510 & Kalupahana & pelitic migmatite & & \\
\hline \multirow[t]{2}{*}{24} & H89081704A & Kalutara & pelitic migmatite & & \\
\hline & H89081801 & & pelitic migmatite & & \\
\hline 25 & Y85111806 & Warakagoda & pelitic migmatite & & \\
\hline 26 & 88120504 & Mahagama & pelitic migmatite & & \\
\hline \multirow[t]{2}{*}{27} & $88120501 B$ & Matugama & pelitic migmatite & & And \\
\hline & 88120503 & & pelitic migmatite & dendrite & And \\
\hline \multirow[t]{3}{*}{28} & YH02120504-3 & Ginigal Pelessa & pelitic migmatite & & \\
\hline & YH02121506C & & pelitic migmatite & dendrite & \\
\hline & YH02121506E & & pelitic migmatite & & \\
\hline 29 & YH18091402-1B & Kataragama & felsic migmatite & & \\
\hline
\end{tabular}




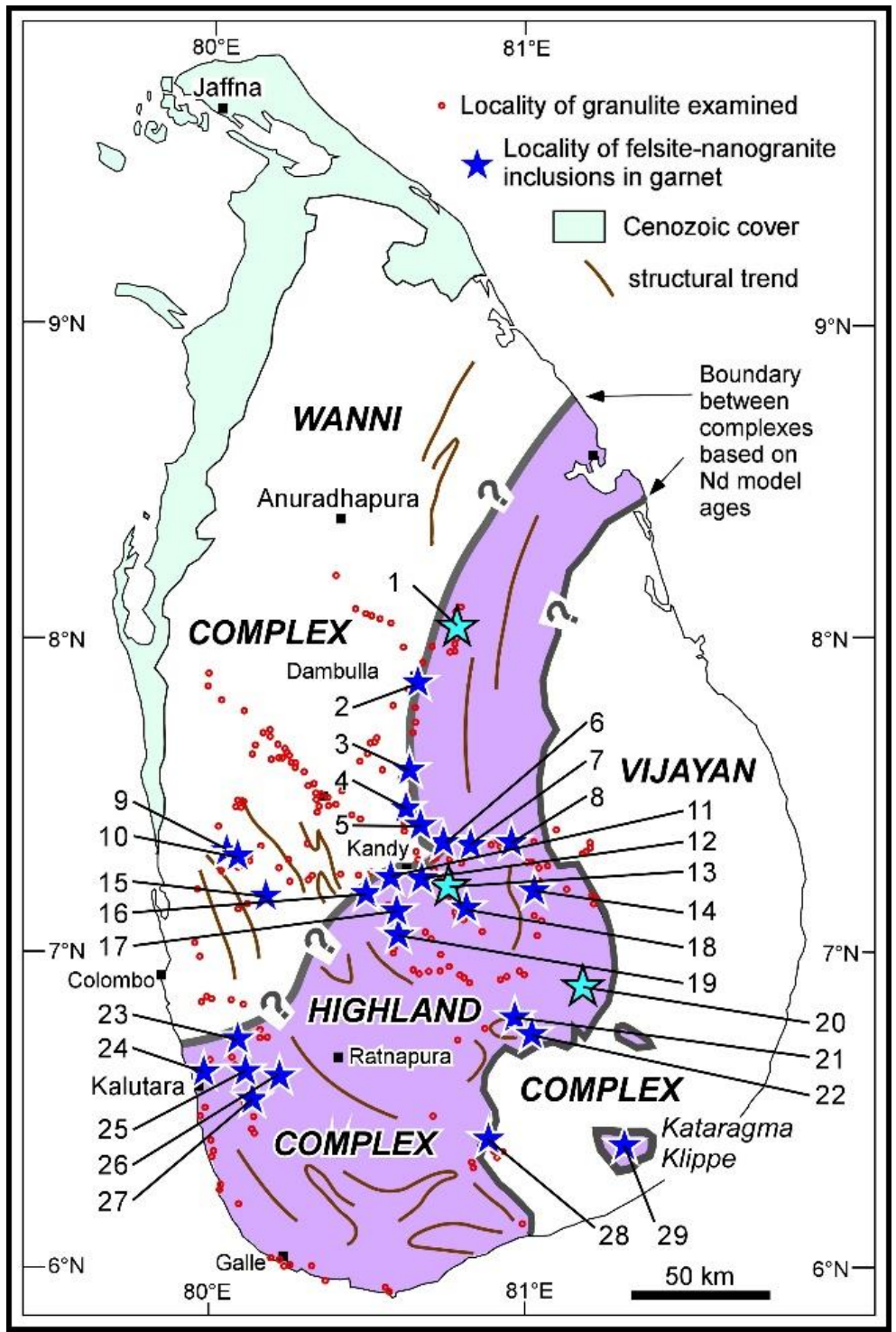

Fig. 1. Map of Sri Lanka showing subdivision of basement high-grade regional metamorphic rocks into three units, Wanni, Highland, and Vijayan complexes from west to east based on Nd model ages (e.g., Cooray, 1994). Localities of granulite-facies rocks containing felsite-nanogranite inclusions in garnet are also shown.

They are characterized not only by far-fromequilibrium crystallization textures such as dendritic and spherulitic crystals of quartz and other minerals but also by porphyritic textures with euhedral-subhedral phenocrysts of quartz and other minerals. The occurrence of FIs is unexpected because granulites are widely inferred to be cooled and exhumed slowly over a period of millions of years (e.g., Spear, 1994; Jamieson and Beaumont, 2011). Cesare et al. (2009) first reported the occurrence of glass inclusions and nanogranites in garnet in a granulite from the Kerala Khondalite Belt, southern India. Nanogranites are cryptocrystalline inclusions consisting of a multiphase aggregate with equigranular, hypidiomorphic to allotriomorphic texture. However, nanogranites exhibit similar features to those of FIs when they are inequigranular and contain granophyric to micrographic intergrowths of quartz and feldspar (Cesare et al., 2011). Because of their similarities, both FIs and nanogranites will be collectively referred to as felsite-nanogranite inclusions (FNIs). FNIs are crystallized felsic and hydrous melt inclusions which were produced by dehydration incongruent melting of biotite and other hydrous minerals during high-grade metamorphism of 
host granulites in continental collision orogens. Although Hiroi et al. (2014) already reported some examples of spherulitic intergrowths of quartz and feldspar in FNIs, additional examples from different localities in Sri Lanka will be documented in some detail together with an experimentally reproduced spherulitic intergrowth of equivalent dimensions to emphasize their importance in obtaining new insight into deep crustal processes in continental collision orogens in this paper.

\section{GEOLOGICAL OUTLINE}

High-grade regional metamorphic rocks occupy most part of Sri Lanka, and have been divided into three geological units (e.g., Cooray, 1994), namely the Wanni Complex (WC) including the Kadugannawa Complex (KC), the Highland Complex (HC), and the Vijayan Complex (VC) from west to east based on $\mathrm{Nd}$ model ages (Milisenda et al., 1988, 1994; Kröner et al., 1991) (Fig. 1). However, the boundary between the $\mathrm{HC}$ and $\mathrm{WC}$ is not well defined, especially in the southwestern part, because of the scarcity of data, and the delineated boundary there appears to be discordant to geological structures. Moreover, there are different interpretations about the boundaries between the $\mathrm{HC}$ and $\mathrm{WC}$ (e.g., Sajeev et al., 2007; Santosh et al., 2014; He et al, 2016a; Kitano et al., 2018) and between the HC and VC (e.g., Kröner et al., 2013; He et al, 2016a, b). Osanai et al. (2016b), Takamura et al. (2016), and Kitano et al. (2018) presented comprehensive review and new geochronological data for the $\mathrm{HC}$ and WC.

\section{THE HIGHLAND COMPLEX (HC)}

The HC yields Nd-model ages of 3400-2000 $\mathrm{Ma}$, and consists of granulite-facies metasedimentary and metaigneous rocks. In the central to northern part of the $\mathrm{HC}$, marble and quartzite layers closely accompanied by khondalite are characteristic and traceable over the distance of $40 \mathrm{~km}$. In contrast, in the southwestern part of the HC, marble and quartzite are scarce (Mathavan et al., 1999), and cordierite-bearing gneisses and orthogneisses are prominent (Perera, 1984; Prame, 1991). Based on such differences in lithology and mineralogy the HC was once subdivided into the Highland Series and Southwestern Group (Cooray, 1984, 1994). Faulhaber and Raith (1991), Raase and Schenk (1994), and Schumacher and Faulhaber (1994) showed an eastward gradual increase in pressure, while Sajeev and Osanai (2005) revealed a regional thermal structure regardless of the boundary between the HC and WC. UHT granulites occur sporadically in the hightemperature part (Osanai et al., 2016a, and references therein).

\section{THE WANNI COMPLEX (WC)}

The WC yields Nd model ages of 1800-1100 $\mathrm{Ma}$, and comprises upper amphibolite- to granulite-facies rocks. Metaigneous rocks are predominant and range from granitic, granodioritic, monzonitic, to tonalitic (Pohl and Emmermann, 1991). The WC also contains non-metamorphic, post-tectonic granites at Tonigala and Galgamuwa (e.g., Cooray, 1984; Hölzl et al., 1991; Cooray, 1994) and carbonatite at Eppawala (Weerakoon et al., 2001; Manthilake et al., 2008; Pitawala and Lottermose, 2012). The $\mathrm{KC}$ is often referred to as "arenas" and shows doubly plunging upright folds (Vitanage, 1972; Almond, 1991; Tani and Yoshida, 1996). Willbold et al. (2004), Santosh et al. (2014) and He et al. (2016a) showed that $\mathrm{VC}$, especially the KC, was once a volcanic arc.

\section{THE VIJAYAN COMPLEX (VC)}

The VC yields Nd-model ages of 1800-1000 $\mathrm{Ma}$, and consists mainly of amphibolite-facies rocks including granitic gneisses, migmatites and hornblende-biotite gneiss with rare quartzite and calc-silicate rocks (Kehelpannala, 1997; Mathavan et al., 1999; Kröner et al., 2013). Kröner et al. (2013) and $\mathrm{He}$ et al. (2016b) demonstrated that the $\mathrm{VC}$ was once a magmatic arc.

\section{MATERIAL AND EXPERIMENTAL PROCEDURE}

\section{PETROGRAPHY AND MINERAL CHEMISTRY}

Careful examination of more than 2000 thin sections of high-grade metamorphic rocks from various part of Sri Lanka (see Fig. 1) was first performed with a Nikon polarized-light microscope Eclipse E6TP-M32 to find FNIs in garnet at Chiba University, Chiba, Japan. Then, secondary electron (SE), backscattered electron (BSE), and cathodoluminescence (CL) images of FNIs were obtained, using a JEOL JSM-5600 scanning electron microscope (SEM) attached to a Link ISIS 300 energy dispersive X-ray spectrometer (EDS) system and an Oxford 
Instruments MiniCL cathodoluminescence detector at Chiba University. X-ray compositional mapping was also performed with the SEM, using a $15 \mathrm{kV}$ accelerating voltage and a $30 \mathrm{nA}$ beam current. Fine-grained minerals (e.g., andalusite, kyanite, grandidierite, and others) were identified with JASCO NRS-1000 and JASCO NRS-3000 laser-Raman spectrometers at the National Institute of Polar Research, Tokyo, Japan and Kyushu University, Fukuoka, Japan, respectively. Fine quartz + feldspar intergrowth textures were observed using a JEOL JXA-8530F field-emission EPMA at Kyushu University. Minerals were analyzed with a JEOL JXA-8230 wavelength dispersive electron probe microanalyzer (EPMA) at Chiba University, a JEOL JXA-8200 wavelength dispersive EPMA at the National Institute of Polar Research, and the JXA-8530F fieldemission EPMA at Kyushu University. Analyses were performed using a $15 \mathrm{kV}$ accelerating voltage and $12 \mathrm{nA}$ beam current, with a $2 \mu \mathrm{m}$ beam diameter. Synthesized oxides and natural minerals were used as standards for major elements. The obtained data were corrected using a JEOL oxide-ZAF correction program. $\mathrm{X}$-ray composition maps were obtained on the same instruments using a $15 \mathrm{kV}$ accelerating voltage, beam currents up to $300 \mathrm{nA}$, and a 1-2 $\mu \mathrm{m}$ beam diameter. Counting times were up to $50 \mathrm{~ms}$.

\section{SAMPLE DESCRIPTION}

Constituent minerals of five representative samples containing FNIs with spherulitic texture are summarized in Table 2.
Sample $88112704 A$ is a migmatitic pelitic to quartzo-feldspathic gneiss. Poikiloblastic garnet contains sporadic inclusions of sillimanite, plagioclase, alkali feldspar, quartz, biotite, ilmenite, and apatite in addition to FNIs (Fig. 2). FNIs in this sample are composed of spherulitic intergrowths of sodic plagioclase + quartz, which are accompanied by more coarse-grained biotite, apatite, and monazite. Biotite in FNIs is more magnesian and contains much less $\mathrm{Ti}$ and $\mathrm{F}$ than biotite in the matrix (Table 3). Estimated peak P-T conditions are $860-950^{\circ} \mathrm{C}$ and $0.8-0.9$ $\mathrm{GPa}$ based on the biotite-garnet $\mathrm{Mg}$-Fe exchange thermometers (Holdaway et al., 1997; Gessmann et al., 1997) and garnet-sillimanite-plagioclasequartz-barometer (Hodges and Crowley, 1985).

Sample 88112901A is a sillimanite-garnet gneiss. Poikiloblastic garnet contains numerous inclusions of sillimanite, plagioclase, alkali feldspar, quartz, biotite, spinel, rutile, ilmenite, monazite, and apatite in addition to FNIs. FNIs contain relatively coarse-grained biotite, sodic plagioclase and quartz surrounding fine spherulitic intergrowth of quartz + alkali feldspar (Fig. 3). Biotite in the FNIs is more magnesian and poor in Ti compared with biotite in the matrix (Table 3). Spinel in direct contact with quartz in garnet (Fig. 3c) is rich in $\mathrm{Zn}$ (Table 3). Estimated peak P-T conditions are 830-900 ${ }^{\circ} \mathrm{C}$ and $0.9-1.0 \mathrm{GPa}$ based on the biotitegarnet $\mathrm{Mg}-\mathrm{Fe}$ exchange thermometers (Holdaway et al., 1997; Gessmann et al., 1997) and garnet-sillimanite-plagioclase-quartz barometer (Hodges and Crowley, 1985).

Table 2. Constituent minerals of samples containing spherulitic felsite-nanogranite inclusions.

\begin{tabular}{|c|c|c|c|c|c|c|c|c|c|c|c|c|c|c|c|c|c|c|}
\hline No & Sample number & Sil & Opx & Grt & $\mathrm{Bt}$ & $\mathrm{Pl}$ & Afs & $\mathrm{Qz}$ & $\mathrm{Rt}$ & $\mathrm{Ilm}$ & $\mathrm{Zrn}$ & Mnz & Ap & $\mathrm{St}^{*}$ & $\mathrm{Hc}^{*}$ & $\mathrm{Crn}^{*}$ & Ky* & And $^{*}$ \\
\hline 1 & $88112704 \mathrm{~A}$ & $\Delta$ & & 0 & 0 & 0 & 0 & 0 & & $\Delta$ & $\Delta$ & $\Delta$ & $\Delta$ & & & & & \\
\hline 13 & $88112901 \mathrm{~A}$ & 0 & & () & $\Delta$ & 0 & 0 & 0 & $\Delta$ & $\Delta$ & $\Delta$ & $\Delta$ & $\Delta$ & & & & & \\
\hline 13 & $88112901 \mathrm{H}$ & & & () & $\Delta$ & 0 & 0 & 0 & $\Delta$ & $\Delta$ & $\Delta$ & $\Delta$ & $\Delta$ & & & & & \\
\hline 13 & G89082204A & 0 & & () & $\Delta$ & $\mathrm{O}$ & O & O & $\Delta$ & $\Delta$ & $\Delta$ & $\Delta$ & $\Delta$ & $\Delta$ & $\Delta$ & $\Delta$ & $\Delta$ & $\Delta^{\# 2}$ \\
\hline 20 & YH18091203C & & 0 & O & O & O & O & O & & $\Delta$ & $\Delta$ & $\Delta$ & $\Delta$ & & & & $\Delta$ & $\Delta$ \\
\hline
\end{tabular}

The mineral abbreviations are after Whitney and Evans (2010).

Modal amount: $\bigcirc$, abundant; $\bigcirc$, moderate; $\triangle$, small.

* In garnet, 'In FNI in garnet,

\#1 Described by Hiroi et al. (1994), $\quad$ \#2 Some in matrix 

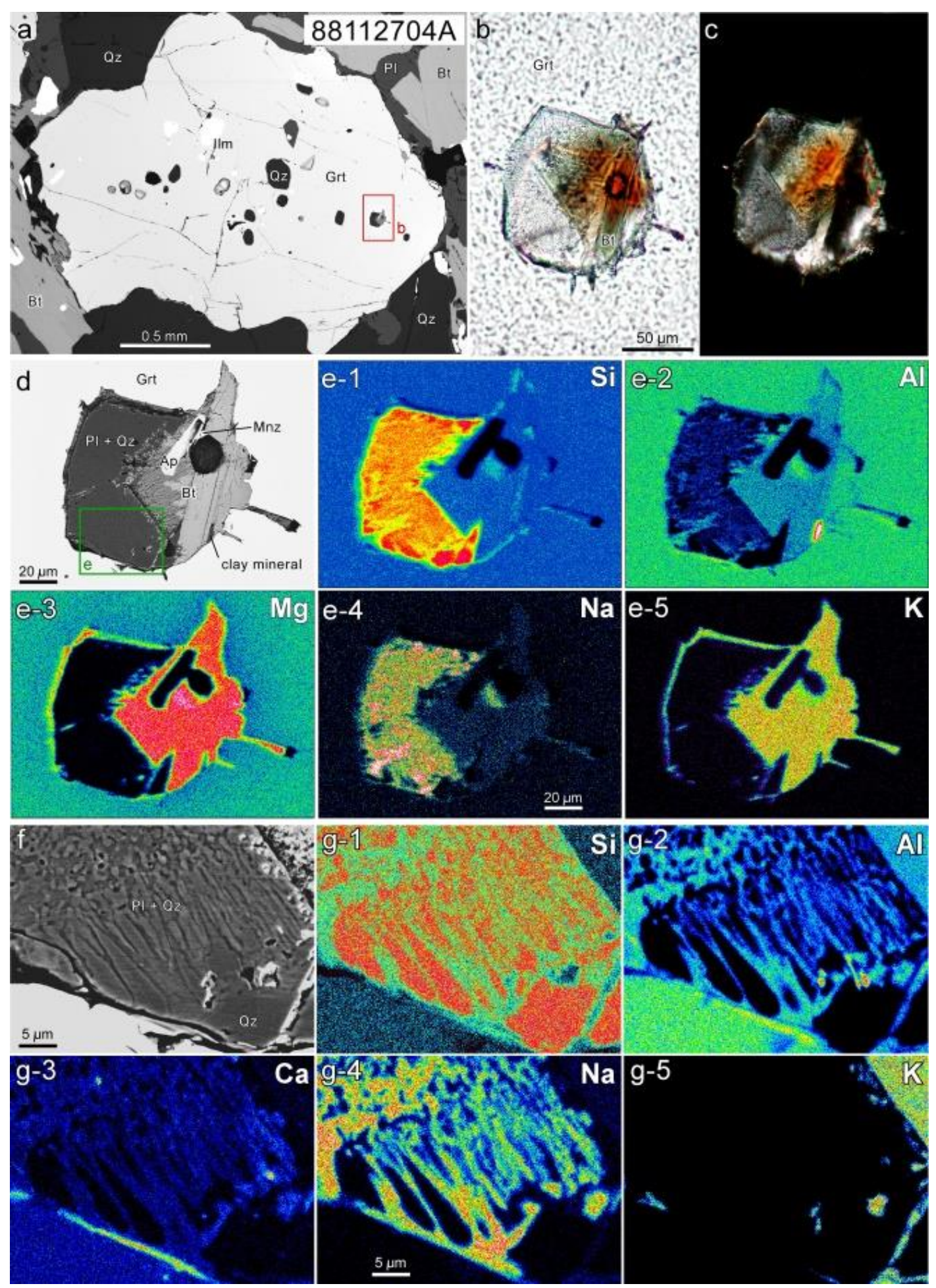

Fig. 2. Backscattered electron (BSE) images ( $a, d$, and $f)$, Plane-polarized light photomicrograph (b), cross-polarized light photomicrograph (c), and X-ray composition maps for $\mathrm{Si}, \mathrm{Al}, \mathrm{Mg}, \mathrm{Na}$, and $\mathrm{K}(\mathrm{e}-1$ to e-5) and for $\mathrm{Si}, \mathrm{Al}, \mathrm{Ca}, \mathrm{Na}$, and $\mathrm{K}(\mathrm{g}-1$ to g-5) of spherulitic In $X$-ray composition maps abundance increases from black to blue to green to yellow to red to white. The mineral abbreviations are after Whitney and Evans (2010). felsite-nanogranite inclusion in garnet in sample 88112704A from locality 1 in Figure 1 . In X-ray composition maps abundance increases from black to blue to green to yellow to red to white. 
Table 3. Representative chemical compositions of minerals in three samples from northern, central and southeastern part of Highland Complex.

\begin{tabular}{|c|c|c|c|c|c|c|c|c|c|c|c|c|c|c|}
\hline \multirow{2}{*}{$\begin{array}{l}\text { Sample } \\
\text { Mineral }\end{array}$} & \multicolumn{4}{|c|}{$88112704 \mathrm{~A}$} & \multicolumn{5}{|c|}{$88112901 \mathrm{~A}$} & \multicolumn{5}{|c|}{ YH18091203C } \\
\hline & $\begin{array}{l}\text { Grt } \\
\text { Core }\end{array}$ & $\begin{array}{l}\text { Pl } \\
\text { In matrix }\end{array}$ & $\begin{array}{l}\mathrm{Bt} \\
\text { In matrix }\end{array}$ & $\begin{array}{l}\mathrm{Bt} \\
\text { In FNI }\end{array}$ & $\begin{array}{l}\text { Grt } \\
\text { Core }\end{array}$ & $\begin{array}{l}\text { Pl } \\
\text { In matrix }\end{array}$ & $\begin{array}{l}\text { Bt } \\
\text { In matrix }\end{array}$ & $\begin{array}{l}\mathrm{Bt} \\
\text { In FNI }\end{array}$ & $\begin{array}{l}\text { Spl } \\
\text { In FNI }\end{array}$ & $\begin{array}{l}\text { Grt } \\
\text { Core }\end{array}$ & $\begin{array}{l}\text { Opx } \\
\text { In matrix }\end{array}$ & $\begin{array}{l}\text { Pl } \\
\text { In matrix }\end{array}$ & $\begin{array}{l}\mathrm{Bt} \\
\text { In matrix }\end{array}$ & $\begin{array}{l}\mathrm{Bt} \\
\text { In FNI }\end{array}$ \\
\hline $\mathrm{SiO}_{2}$ & 39.80 & 62.23 & 35.03 & 38.10 & 39.46 & 62.31 & 35.17 & 35.99 & 0.04 & 38.20 & 50.65 & 57.34 & 36.53 & 39.27 \\
\hline $\mathrm{TiO}_{2}$ & 0.04 & 0.00 & 4.84 & 0.57 & 0.06 & 0.00 & 7.55 & 2.64 & 0.05 & 0.08 & 0.06 & 0.02 & 5.76 & 0.04 \\
\hline $\mathrm{Al}_{2} \mathrm{O}_{3}$ & 22.25 & 24.68 & 16.94 & 17.65 & 22.08 & 23.13 & 15.96 & 19.87 & 61.86 & 21.58 & 2.57 & 25.98 & 13.61 & 18.65 \\
\hline $\mathrm{Cr}_{2} \mathrm{O}_{3}$ & 0.04 & 0.00 & 0.06 & 0.06 & 0.00 & 0.09 & 0.01 & 0.01 & 0.10 & 0.04 & 0.00 & 0.00 & 0.08 & 0.03 \\
\hline $\mathrm{FeO} *$ & 28.93 & 0.05 & 14.78 & 10.54 & 31.36 & 0.02 & 15.32 & 13.25 & 24.91 & 29.64 & 28.33 & 0.14 & 17.12 & 8.27 \\
\hline $\mathrm{MnO}$ & 0.99 & 0.00 & 0.02 & 0.04 & 0.32 & 0.00 & 0.00 & 0.06 & 0.00 & 0.72 & 0.29 & 0.05 & 0.00 & 0.00 \\
\hline $\mathrm{ZnO}$ & n.d. & n.d. & n.d. & n.d. & n.d. & n.d. & n.d. & n.d. & 7.05 & n.d. & n.d. & n.d. & n.d. & n.d. \\
\hline $\mathrm{MgO}$ & 9.27 & 0.00 & 13.04 & 18.55 & 7.70 & 0.00 & 12.12 & 13.62 & 7.19 & 6.95 & 17.94 & 0.03 & 12.58 & 16.50 \\
\hline $\mathrm{CaO}$ & 1.08 & 6.03 & 0.00 & 0.01 & 1.34 & 4.45 & 0.02 & 0.04 & 0.02 & 3.79 & 0.37 & 9.02 & 0.03 & 0.43 \\
\hline $\mathrm{Na}_{2} \mathrm{O}$ & 0.00 & 8.30 & 0.07 & 0.41 & 0.03 & 9.49 & 0.09 & 0.08 & 0.00 & 0.01 & 0.02 & 6.74 & 0.05 & 0.74 \\
\hline $\mathrm{K}_{2} \mathrm{O}$ & 0.01 & 0.46 & 9.83 & 8.51 & 0.00 & 0.24 & 9.84 & 9.87 & 0.01 & 0.01 & 0.01 & 0.25 & 9.78 & 8.53 \\
\hline $\mathrm{F}$ & n.d. & n.d. & 0.62 & 0.26 & n.d. & n.d. & 0.15 & 0.21 & n.d. & n.d. & n.d. & n.d. & n.d. & n.d. \\
\hline $\mathrm{Cl}$ & n.d. & n.d. & 0.01 & 0.00 & n.d. & n.d. & 0.14 & 0.15 & n.d. & n.d. & n.d. & n.d. & n.d. & n.d. \\
\hline total & 102.41 & 101.75 & 94.98 & 94.60 & 102.35 & 99.73 & 96.28 & 95.67 & 101.23 & 101.02 & 100.24 & 99.57 & 95.54 & 92.46 \\
\hline $\mathrm{O}$ & 12 & 8 & 22 & 22 & 12 & 8 & 22 & 22 & 4 & 12 & 6 & 8 & 22 & 22 \\
\hline $\mathrm{Si}$ & 3.003 & 2.721 & 5.296 & 5.562 & 3.007 & 2.773 & 5.255 & 5.316 & 0.001 & 2.966 & 1.935 & 2.589 & 5.532 & 5.770 \\
\hline $\mathrm{Ti}$ & 0.002 & 0.000 & 0.550 & 0.063 & 0.003 & 0.000 & 0.849 & 0.293 & 0.001 & 0.005 & 0.002 & 0.001 & 0.656 & 0.004 \\
\hline $\mathrm{Al}$ & 1.978 & 1.272 & 3.018 & 3.037 & 1.983 & 1.213 & 2.811 & 3.459 & 1.992 & 1.975 & 0.116 & 1.382 & 2.429 & 3.229 \\
\hline $\mathrm{Cr}$ & 0.002 & 0.000 & 0.007 & 0.007 & 0.000 & 0.003 & 0.001 & 0.001 & 0.002 & 0.002 & 0.000 & 0.000 & 0.010 & 0.003 \\
\hline $\mathrm{Fe}$ & 1.825 & 0.002 & 1.869 & 1.287 & 1.998 & 0.001 & 1.914 & 1.637 & 0.569 & 1.924 & 0.905 & 0.005 & 2.168 & 1.016 \\
\hline $\mathrm{Mn}$ & 0.063 & 0.000 & 0.003 & 0.005 & 0.021 & 0.000 & 0.000 & 0.008 & 0.000 & 0.047 & 0.009 & 0.002 & 0.000 & 0.000 \\
\hline $\mathrm{Zn}$ & & & & & & & & & 0.142 & & & & & \\
\hline $\mathrm{Mg}$ & 1.043 & 0.000 & 2.939 & 4.037 & 0.875 & 0.000 & 2.700 & 2.999 & 0.293 & 0.805 & 1.022 & 0.002 & 2.840 & 3.614 \\
\hline $\mathrm{Ca}$ & 0.087 & 0.283 & 0.000 & 0.002 & 0.109 & 0.212 & 0.003 & 0.006 & 0.001 & 0.315 & 0.015 & 0.436 & 0.005 & 0.068 \\
\hline $\mathrm{Na}$ & 0.000 & 0.704 & 0.021 & 0.116 & 0.004 & 0.819 & 0.026 & 0.023 & 0.000 & 0.002 & 0.001 & 0.590 & 0.015 & 0.211 \\
\hline $\mathrm{K}$ & 0.001 & 0.026 & 1.896 & 1.585 & 0.000 & 0.014 & 1.876 & 1.860 & 0.000 & 0.001 & 0.000 & 0.014 & 1.889 & 1.599 \\
\hline $\mathrm{F}$ & & & 0.296 & 0.120 & & & 0.071 & 0.098 & & & & & & \\
\hline $\mathrm{Cl}$ & & & 0.003 & 0.000 & & & 0.035 & 0.038 & & & & & & \\
\hline total & 8.005 & 5.007 & 15.599 & 15.702 & 8.000 & 5.035 & 15.438 & 15.61 & 3.001 & 8.042 & 4.006 & 5.022 & 15.544 & 15.514 \\
\hline $\mathrm{Mg} /(\mathrm{Mg}+\mathrm{Fe})$ & 0.364 & & 0.611 & 0.758 & 0.305 & & 0.585 & 0.647 & 0.340 & 0.295 & 0.530 & & 0.567 & 0.781 \\
\hline Alm & 0.605 & & & & 0.665 & & & & & 0.622 & & & & \\
\hline Prp/An & 0.345 & 0.279 & & & 0.291 & 0.203 & & & & 0.260 & & 0.419 & & \\
\hline $\mathrm{Sps} / \mathrm{Ab}$ & 0.021 & 0.695 & & & 0.007 & 0.784 & & & & 0.015 & & 0.567 & & \\
\hline Grs/Or & 0.029 & 0.025 & & & 0.036 & 0.013 & & & & 0.102 & & 0.014 & & \\
\hline
\end{tabular}

* Total $\mathrm{Fe}$ as $\mathrm{FeO}$

n.d. $=$ not determined 


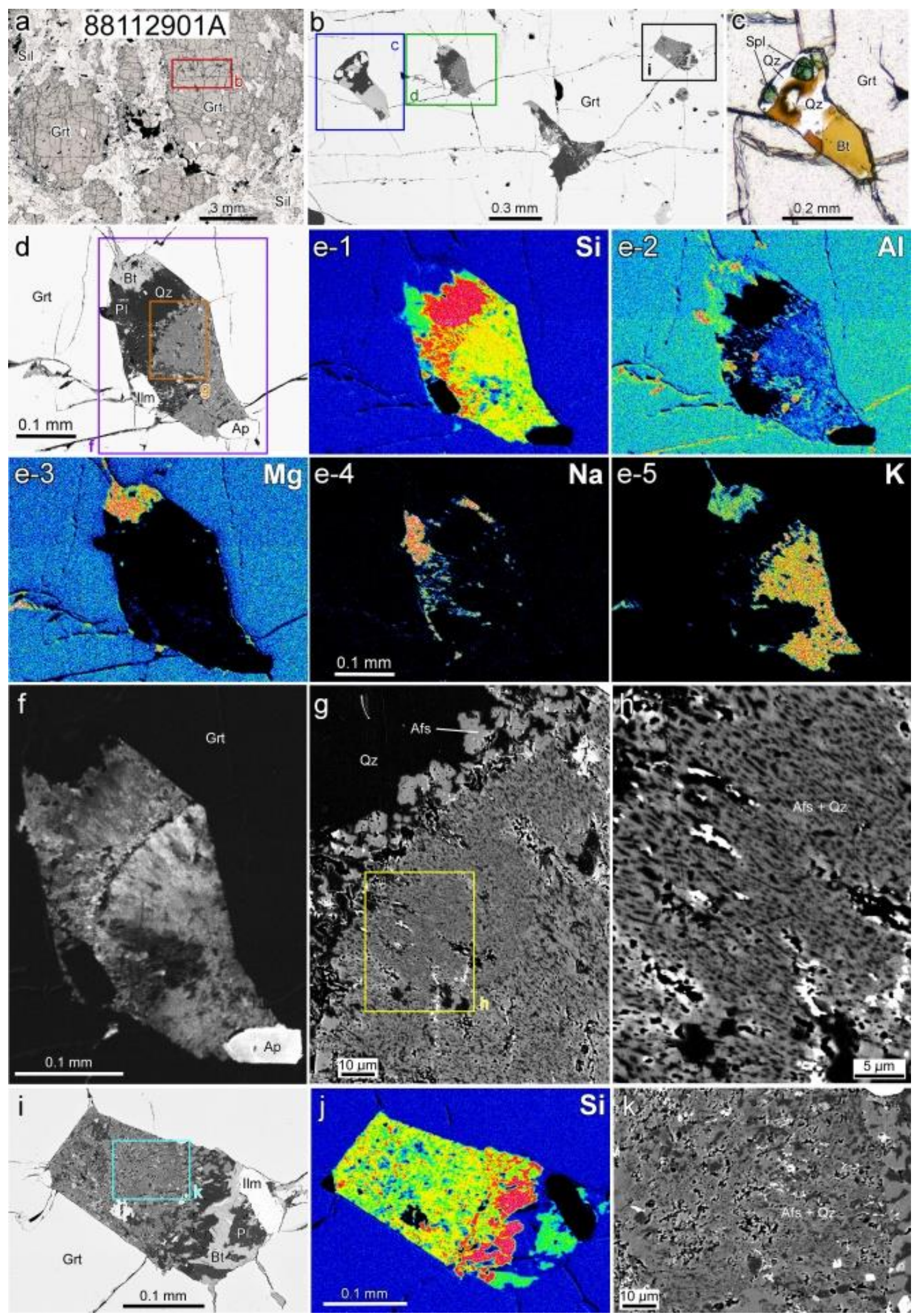

Fig. 3. Plane-polarized light photomicrographs ( $a$ and $c$ ), BSE images ( $b, d, g, h, i$, and $k$ ), $X$-ray composition maps for $\mathrm{Si}, \mathrm{Al}, \mathrm{Mg}, \mathrm{Na}$, and $\mathrm{K}(e-1$ to e-5) and for $\mathrm{Si}(\mathrm{j})$, and scanning electron microscope cathodoluminescence (SEM-CL) image of spherulitic felsitenanogranite inclusions in garnet in sample 88112901A from locality 13 in Figure 1. 

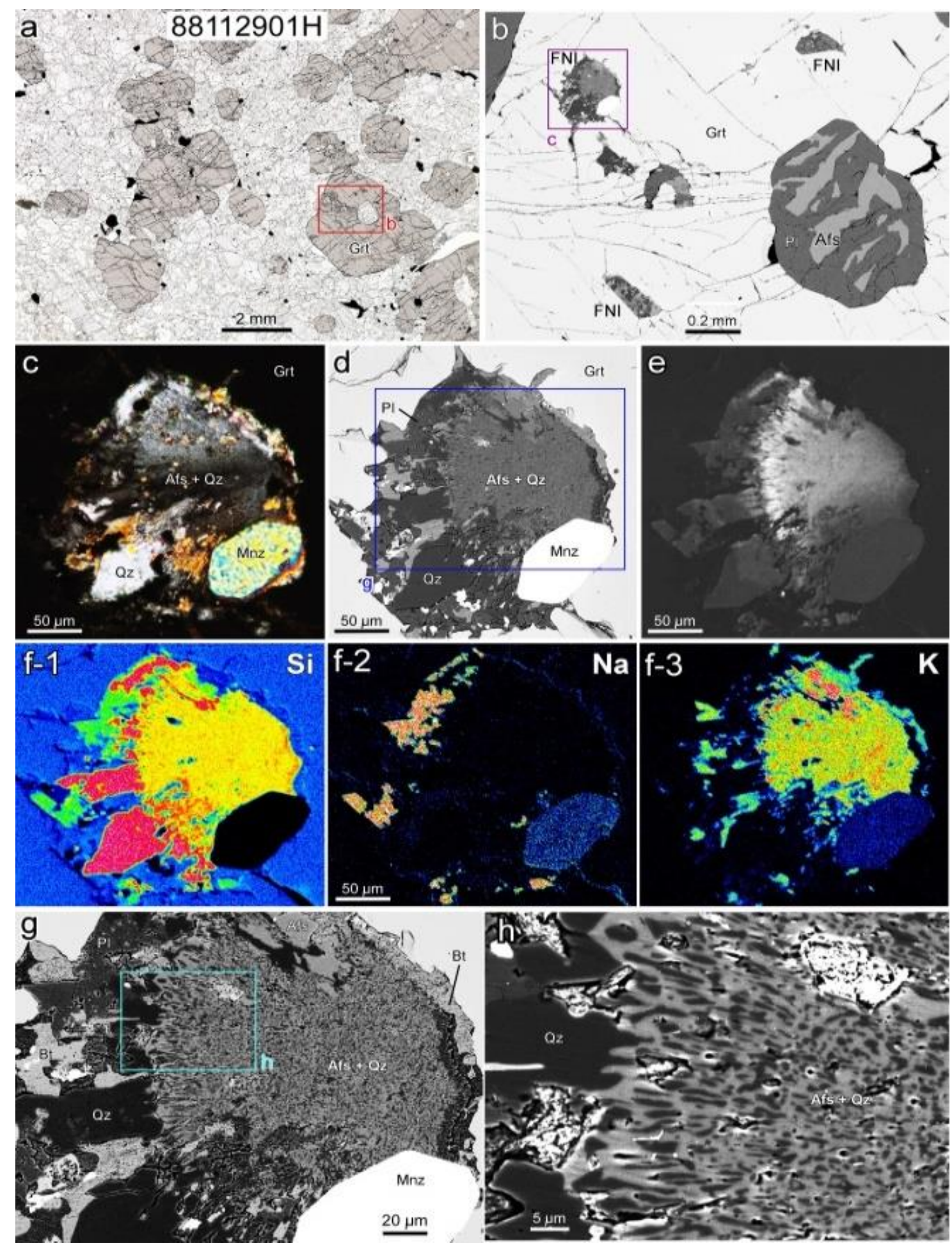

Fig. 4. Plane-polarized light photomicrograph (a), cross-polarized light photomicrograph (c), BSE images ( $b, d, g$ and $h$ ), SEM-CL image (e), and X-ray composition maps for Si, $N a$, and $K$ (f-1 to $f$-3) of spherulitic felsite-nanogranite inclusion in garnet in sample $88112901 \mathrm{H}$ from locality 13 in Figure 1. 

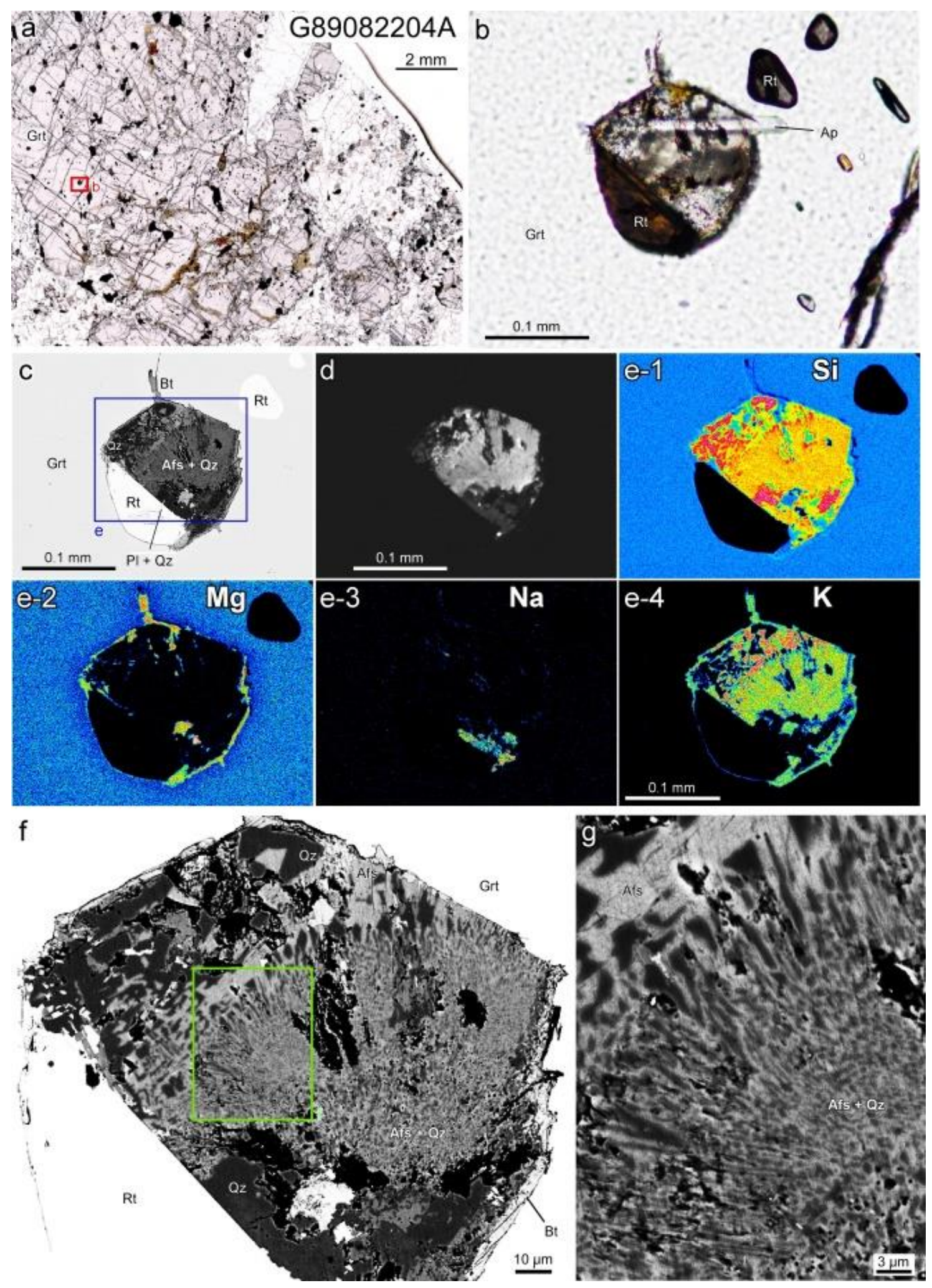

Fig. 5. Plane-polarized light photomicrographs ( $a$ and $b$ ), BSE images (c, $f$, and $g$ ), SEM-CL image (d), and X-ray composition maps for $\mathrm{Si}, \mathrm{Mg}$, $\mathrm{Na}$, and $\mathrm{K}(\mathrm{e}-1$ to e-4) of spherulitic felsite-nanogranite inclusion in garnet in sample G89082204A from locality 13 in Figure 1. 


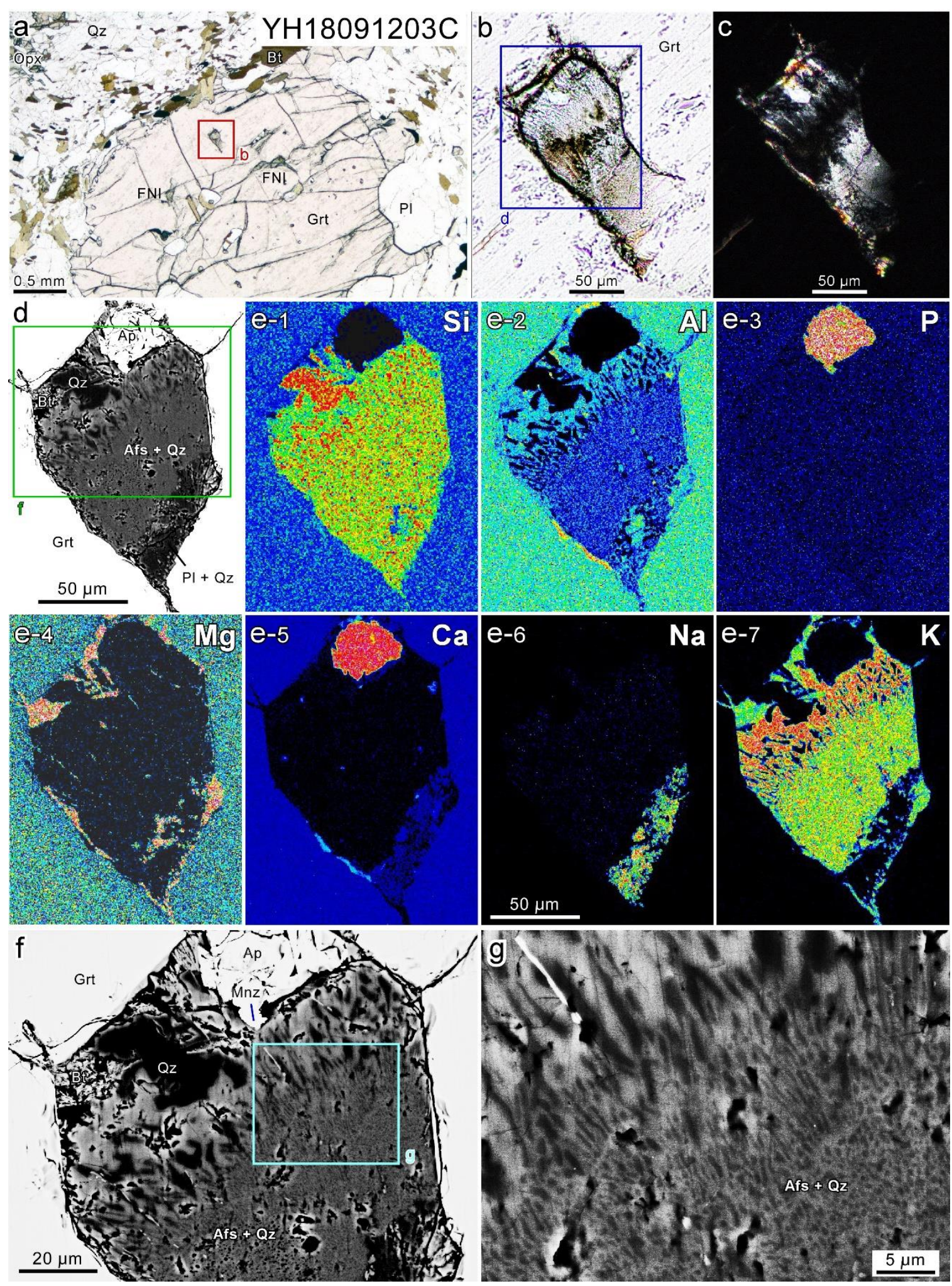

Fig. 6. Plane-polarized light photomicrographs $(a$ and $b)$, cross-polarized light photomicrograph (c), BSE images (d, $f$, and $g$ ), and X-ray composition maps for Si, Al, $P$, $\mathrm{Mg}, \mathrm{Ca}, \mathrm{Na}$, and $\mathrm{K}(\mathrm{e}-1$ to e-7) of spherulitic felsite-nanogranite inclusion in garnet in sample YH18091203C from locality 20 in Figure 1. 
Sample $88112901 \mathrm{H}$ is a sillimanite-free garnetrich gneiss. Poikiloblastic garnet contains many inclusions of sillimanite, plagioclase, alkali feldspar, quartz, biotite, rutile, ilmenite, monazite, and apatite in addition to FNIs. It is noteworthy that some inclusion feldspars are coarse-grained mesoperthite in marked contrast with fine-grained FNIs with variable textures even in the same garnet (Fig. 4). In FNI showing spherulitic texture fine intergrowth of quartz + alkali feldspar is overgrown by more coarsegrained biotite, sodic plagioclase and quartz.

Sample G89082204A is a sillimanite-garnet gneiss. Poikiloblastic garnet contains numerous inclusions of quartz, plagioclase, alkali feldspar, sillimanite, kyanite, corundum, staurolite, hercynite, biotite, rutile, ilmenite, apatite, monazite, and carbonate minerals in addition to FNIs. Kyanite and staurolite are relict prograde minerals, while local andalusite + carbonate mineral association is of retrograde origin replacing garnet from outside and along cracks (Hiroi et al., 1994). Spherulitic FNI consists mainly of quartz + alkali feldspar intergrowth with minor quartz + sodic plagioclase intergrowth besides rutile and apatite (Fig. 5).

Sample YH18091203C is a well-foliated intermediate granulite containing orthopyroxene. Subidioblastic to xenoblastic and poikiloblastic garnet contains inclusions of plagioclase, quartz, biotite, ilmenite, monazite, and apatite in addition to FNIs, which show variable textures even in the same garnet grain (Fig. 6). It is notable that the spherulitic FNI is inhomogeneous, being composed mainly of alkali feldspar + quartz intergrowth with minor sodic plagioclase + quartz intergrowth. Biotite in the FNIs is more magnesian and poor in $\mathrm{Ti}$ compared with biotites showing different modes of occurrence, such as those included within garnet separately from the FNIs and in the matrix (Table 3). Estimated peak temperature by the biotite-garnet $\mathrm{Mg}$-Fe exchange thermometers (Holdaway et al. 1997; Gessmann et al., 1997) is 970-980 ${ }^{\circ} \mathrm{C}$, while estimated pressure is about 0.9 GPa based on the garnet-plagioclaseorthopyroxene-quartz barometer of Perkins and Chipera (1985).

\section{DYNAMIC CRYSTALLIZATION EXPERIMENT}

Crystallization of melt takes place at various undercooling $(\Delta T)$, which is the difference between liquidus temperature and crystallization temperature, resulting in different morphologies of crystals (e.g., Sunagawa, 2005). Spherulitic texture is typically formed at large $\Delta \mathrm{T}\left(>200^{\circ} \mathrm{C}\right)$ (e.g., Maneta and Baker, 2014). Dynamic (time dependent) crystallization experiments have been performed from 1970s (e.g., Lofgren, 1974; Fenn, 1986; Swanson and Fenn, 1986; MacLellan and Trembath, 1991; Baker and Freda, 2001; Roskosz et al., 2005; London, 2008; Hammer, 2008; Maneta and Baker, 2014; Sirbescu et al., 2017, and references therein). Similar experimental study was conducted to reproduce observed mineral textures of FNIs with an internally heated, argon-pressurized vessel at Chiba University, Japan (Sun et al. unpublished data). The starting material is granitic $\left(\mathrm{SiO}_{2}\right.$ 79.41; $\mathrm{TiO}_{2}$ 0.04; $\mathrm{Al}_{2} \mathrm{O}_{3}$ 11.41; total $\mathrm{Fe}$ as $\mathrm{FeO} 1.05$; $\mathrm{MnO} 0.04 ; \mathrm{MgO} 0.03$; $\mathrm{CaO} 0.47 ; \mathrm{Na}_{2} \mathrm{O} 4.07 ; \mathrm{K}_{2} \mathrm{O} 3.45 ; \mathrm{P}_{2} \mathrm{O}_{5} 0.02$; total $100.00 \mathrm{wt} \%)$. The experimental procedure is schematically shown in Figure 7a. The starting material was first completely melted at $950{ }^{\circ} \mathrm{C}$ and $0.2 \mathrm{GPa}$ for 24 hours. Then, crystallization experiment started with cooling at various rates to the desired temperature ranging from 500 to $700{ }^{\circ} \mathrm{C}$. Then the experiment was held at the temperature for $0-1004$ hours to accumulate data of variable textural development for the granitic composition with variable amounts of water. Obtained data are in harmony with the published experimental results with similar composition and $\Delta \mathrm{T}$ (e.g., Maneta and Baker, 2014; Sirbescuet al., 2017, and references therein).

In Figure $7 b$, a representative BSE image of the run product of isothermal crystallization of the granitic material with $2.4 \mathrm{wt} \%$ water at $700^{\circ} \mathrm{C}$ $\left(\Delta \mathrm{T} \sim 230^{\circ} \mathrm{C}\right)$ and $0.2 \mathrm{GPa}$ for 1004 hours is presented together with the natural example in sample YH18091203C for comparison. Both texture and grain size of the spherulitic intergrowths in Figure $7 \mathrm{~b}$ are almost equivalent to each other, indicating that observed spherulitic textures of FNIs are well reproduced by the crystallization duration up to 1004 hours. Run products of shorter crystallization durations 134 and 30 hours are much more fine-grained, submicrometer- and micrometer-scale respectively. In general, the longer crystallization duration is, the more coarsegrained and larger run product is. The experimental method, procedure, and results will be presented elsewhere. 

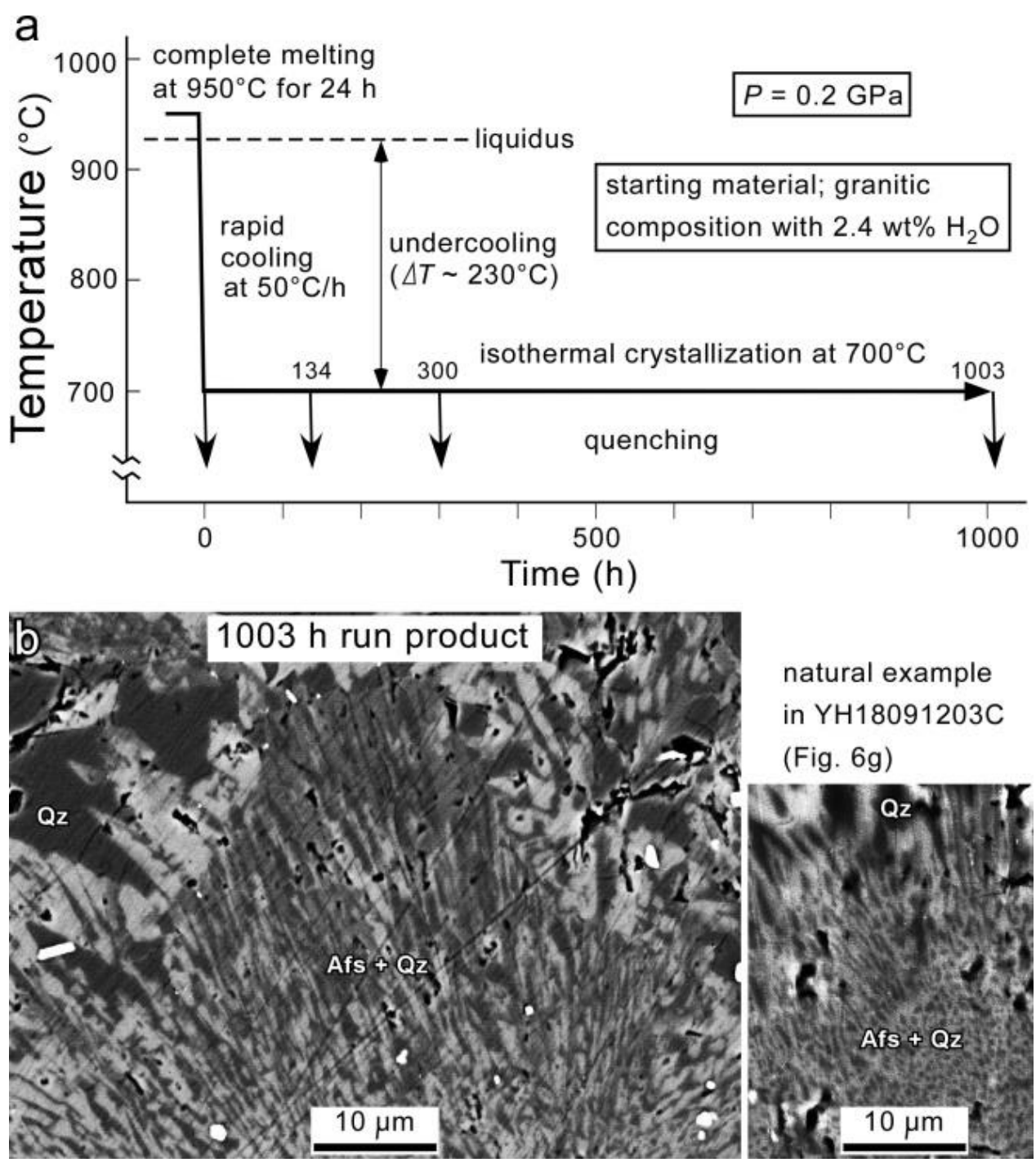

Fig. 7a. Schematic illustration of dynamic (time dependent) isothermal crystallization experimental procedure (a) and BSE images of $1004 \mathrm{~h}$ isothermal crystallization run product at $700^{\circ} \mathrm{C}$ and $0.2 \mathrm{GPa}$ and natural example (YH18091203C) (b). Run products of 138 and $300 \mathrm{~h}$ isothermal crystallization are submicrometer- and micrometer-scale spherulitic intergrowths, respectively.

\section{DISCUSSION AND CONCLUSIONS}

A schematic model of FNI-forming and preserving processes is shown in Figure 8 after Hiroi et al. (2014, 2019). The 'isobaric cooling of trapped melts in garnet' of stage (1) in Hiroi et al. (2014) should be changed to (2) 'cooling of trapped melts with substantial overpressure caused by the large difference in compressibility between melt inclusions and host garnet' (Angel et al., 2014, 2015; Ferrero et al., 2016, 2018; Hiroi et al., 2019). The cracking of host garnet of stage (3) may have been caused by deformation of host rocks during exhumation as well as the deviatoric stresses in the host garnet caused by overpressure (e.g., Angel et al., 2015; Ferrero et al., 2016). The decompression caused by cracking induces instantaneous $\mathrm{H}_{2} \mathrm{O}$ loss from hydrous melt, which imposes effective undercooling of trapped melts resulting in farfrom-equilibrium crystallization to form the characteristic mineral textures of FNIs. The significance of andalusite often present in FNIs is discussed by Hiroi et al. (2019). The observed spherulitic intergrowths of quartz + feldspar in FNIs are reproducible by experiments for the 


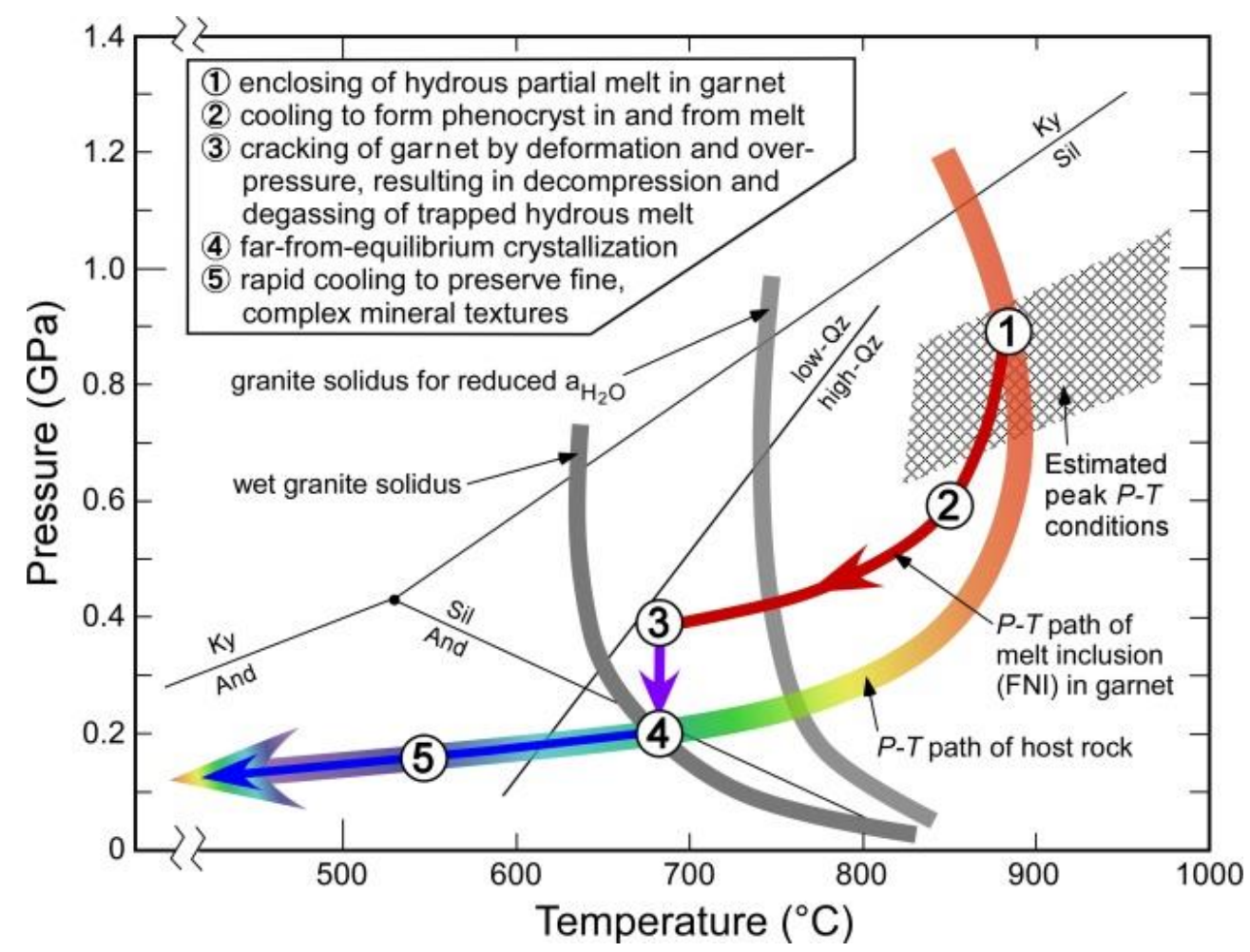

Fig. 8. P-T diagram showing schematic P-T paths followed by melt inclusion (FNI) in garnet and host rock. Estimated peak P-T conditions of samples 88112704A, 88112901A, and YH18091203C based on the chemical compositions of minerals in Table 3, biotite-garnet Mg-Fe exchange thermometers (Holdaway et al., 1997; Gessmann et al., 1997), garnet-sillimaniteplagioclase-quartz barometer (Hodges and Crowley, 1985), and garnet-plagioclaseorthopyroxene-quartz barometer (Perkins and Chipera, 1985). FNI-forming and preserving processes consist of five stages (1) to (5) (see text for more detail). Wet granite solidus and granite solidus for reduced $\mathrm{H}_{2} \mathrm{O}$ activity are drawn to show the degassing effect on solidification temperature. Liquidus temperature also increases by degassing.

duration up to 1000 hours, as shown above. If the run product is held at the same $P-T$ conditions for longer duration, coarsening and recrystallization (Ostwald ripening) to destroy the fine spherulitic texture will take place. Therefore, rapid cooling is inevitable to preserve the fine textures of FNIs after their formation. The cooling history of metamorphic rocks is usually determined by measuring the ages of several different minerals, each with a different closure temperature. In general, slow cooling near the metamorphic peak is followed by rapid cooling (10-20 $\left.{ }^{\circ} \mathrm{C} / \mathrm{Ma}\right)$ between 550 and $300{ }^{\circ} \mathrm{C}$ (Spear, 1994). Numerical models of syn- and post-convergent ductile flow at $\mathrm{T}>500{ }^{\circ} \mathrm{C}$ may reproduce the $P-T$ path follwed by granulites well (e.g., Jamieson et al., 2010, Jamieson and Beaumont, 2011), but the rapid cooling path (5) in Figure 8 has not been performed yet. In this connection, fluid released from crystallizing partial melts may play a significant role in reducing rock strength in discrete high-strain zones during cooling, as Hiroi et al. (2014) pointed out. Since crystallization of partial melts does not exactly reverse dehydration melting processes, crystallization inevitably leads to local fluid overpressures and hence hydraulic fracturing or fault lubrication.

The rapid cooling mechanism of huge granulite masses and relevant geological processes in the depths of continental collision orogens are yet to be solved. Sri Lanka is the key place to unravel the problems because of the most widespread but restricted occurrence of FNIs along the marginal part of the HC, as shown in Figure 1, in addition to accumulated geological, geochemical, and geochronological data. 


\section{ACKNOWLEDGEMENTS}

I thank many researchers in Sri Lanka for their faithful collaboration and kind supports, in particular L.R.K. Perera, B. Prame, J.M.S. Jayatileke, V. Mathavan, K.V. W. Kehelpannala, M.S.Rupasinghe, N.S. Ranasinghe, M.R.D. Fernando, L.K. Seneviratne, P.W. Vitanage and P.G. Cooray. I am grateful to the Executive Committee Members of the Geological Society of Sri Lanka (R. Premasiri, P. Jayasinghe and L. V. Ranaweera), A.A.J.K. Gunatilake and Sanjeewa P.K. Malaviarachchi for the arrangements to hold the $25^{\text {th }}$ Ananda Coomaraswamy Oration on $22^{\text {nd }}$ August, 2019, in Sri Lanka. I also thank co-editors of the Journal of the Geological Society of Sri Lanka (A.S. Ratnayake and H.M.K.N.H. Koralegedara) for their editorial handling. I am grateful to those with whom I have enjoyed the joint study of FNIs and granulites from Sri Lanka; A. Yanagi, M. Kato, Y. Sun, T. Kobayashi, N. Furukawa, Y. Ogo, K. Nanba, F. Higashino, M. Kayama, T. Adachi, T. Kawakami, T. Hokada, A. Miyake, K. Sajeev, M. Satish-Kumar, N. Tsuchiya, M. Ishikawa, M. Owada, Y. Osanai, Y. Motoyoshi, S.L. Harley, D.J. Ellis, M. Brown, K. Shiraishi, H. Matsueda, E.S. Grew, M. Asami, H. Kagami and M. Yoshida. Funding for the research was from the Japanese Government (Grant-in-Aid for Scientific Research; 63041031, 18K03789), Chiba University, National Institute of Polar Research, Japan, and Geological Survey and Mines Bureau of Sri Lanka.

\section{REFERENCES}

Angel, R. J, Mazzucchelli, M. L, Alvaro, M., Nimis, P. and Nestola, F. (2014) Geobarometry from host-inclusion systems: the role of elastic relaxation. American Mineralogist, 99: 2146-2149.

Angel, R. J., Nimis, P., Mazzucchelli, M. L., Alvaro, M. and Nestola, F. (2015) How large are departures from lithostatic pressure? Constraints from host-inclusion elasticity. Journal of Metamorphic Geology, 33: 801813.

Almond, D.C. (1991) Arena gneiss and Kandy gneiss - a proposed subdivision of the Highland Series around Kandy and its significance. Journal of Geological Society of Sri Lanka, 3: 41-50.
Baker, D.R. and Freda, C. (2001) Eutectic crystallization in the undercooled orthoclasequartz- $\mathrm{H}_{2} \mathrm{O}$ system: experiments and simulations. European Journal of Mineralogy, 13: 453-466.

Cesare, B., Ferrero, S., Salvioli-Mariani, E., Pedron, D. and Cavallo, A. (2009) "Nanogranite" and glassy inclusions: the anatectic melt in migmatites and granulites. Geology, 37: 627-630.

Cesare, B., Acosta-Vigil, A., Ferrero, S. and Bartoli, O. (2011) Melt inclusions in migmatites and granulites. In The Science of Microstructure-Part II (Forster, M.A. and Fitz Gerald, J.D. Eds.). Journal of Virtual Explorer, Electronic Edition (ISSN: 14418142) http://dx.doi.org/10.3809/jvirtex.2011.00268 (paper 2).

Cooray, P.G. (1984) An introduction to the geology of Sri Lanka (Ceylon) second ed., National Museums of Sri Lanka Publication, pp 340.

Cooray, P. G. (1994). The Precambrian of Sri Lanka: a historical review. Precambrian Res. 66: 3-18.

Dharmapriya, P.L., Malaviarachchi, S.P., Santosh, M., Tang, L. and Sajeev, K. (2015) Late Neoproterozoic ultrahigh-temperature metamorphism in the Highland Complex, Sri Lanka. Precambrian Research, 271: 311333.

Dissanayake, C.B. (1986) The origin of vein graphite of Sri Lanka: biogenic or abibiogenic. L.J.D Fernando Felicitation Volume, Geological Society of Sri Lanka, 131-140.

Ellis, D.J. and Hiroi, Y. (1997). Secondary siderite-oxide-sulphide and carbonateandalusite assemblages in cordierite granulites from Sri Lanka: Post-granulite facies fluid evolution during uplift. Contributions to Mineralogy and Petrology, 127: 315-335.

Erdosh, D. (1970) Geology of Bogala mine, Ceylon and the origin of vein type graphite. Mineral Deposita, 5: 375-382.

Faulhaber, S. and Raith, M. (1991) Geothermometry and geobarometry of highgrade rocks: a case study on garnetpyroxene granulites in southern Sri Lanka. Mineralogical Magazine, 55: 17- 40.

Fenn, P.M. (1986) On the origin of graphic granite: American Mineralogist, 71: 325330 . 
Ferrero, S., Ziemann, M.A., Angel, R.J., O'Brien, P.J. and Wunder, P.J. (2016) Kumdykolite, kokchetavite, and cristobalite crystallized in nanogranites from felsic granulites, Orlica Snieznik Dome (Bohemian Massif): not evidence for ultrahigh pressure conditions. Contributions to Mineralogy and Petrology, 171, 3. https://doi.org/10.1007/s00410-015-1220-x

Ferrero, S., Godard, G., Palmeri, R., Wunder, B. and Cesare, B. (2018) Partial melting of ultramafic granulites from Dronning Maud Land, Antarctica: Constraints from melt inclusions and thermodynamic modeling. American Mineralogist, 103: 610-622.

Gessmann, C.K., Spiering, B., and Raith, M. (1997) Experimental study of the $\mathrm{Fe}-\mathrm{Mg}$ exchange between garnet and biotite: Constraints on the mixing behavior and analysis of the cation-exchange mechanisms. American Mineralogist, 82: 1225-1240.

Grew, E.S., Hiroi, Y., Motoyoshi, Y., Kondo, Y., Jayatileke, J.M.S. and Marquez, N. (1995) Iron-rich kornerupine in sheared pegmatite from the Wanni Complex, at Homagama, Sri Lanka. European Journal of Mineralogy, 7: 623-636.

Hansen, E.C., Janardhan, A.S., Newton, R.C., Prame, W.K.B.N. and Ravindra Kumar, G.R. (1987) Arrested charnockite formation in southern India and Sri Lanka. Contributions to Mineralogy and Petrology, 96: 225-244.

Hapuarachchi, D.J.A.C. (1977) Decarbonation reactions and the origin of vein graphite in Sri Lanka. Journal of the National Science Council of Sri Lanka, 5: 29-32.

He X.-F, Santosh, M., Tsunogae, T. and Malaviarachchi, S.P.K. (2016a) Early to late Neoproterozoic magmatism and magma mixing-mingling in Sri Lanka: Implications for convergent margin processes. Gondwana Research, 32: 151-180.

He, X.-F., Santosh, M., Tsunogae, T., Malaviarachchi, S.P.K. and Dharmapriya, P.L. (2016b) Neoproterozoic arc accretion along the eastern suture in Sri-Lanka during Gondwana assembly. Precambrian Research, 279: 57-80.

Hewathilake, H.P.T.S., Balasooriya, N.W.B., Nakamura, Y., Pitawala, H.M.T.G.A., Athula, H.W.M., Wijayasinghe, C. and Satish-Kumar, M. (2018) Geochemical, structural and morphological characterization of vein graphite deposits of Sri Lanka: Witness to carbon rich fluid activity, Journal of Mineralogical and Petrological Sciences, 113: 96-105.

Hiroi, Y., Yoshida, M. and Vitanage, P.W. (1987) Relict kyanite in the Highland and Southwest gneisses in Sri Lanka; evidence of prograde metamorphism and a characteristic common with the Lützow-Holm Bay complex in East Antarctica. Special Publication 3, Geological Society of Sri Lanka. pp 28.

Hiroi, Y., Asami, M., Cooray, P. G., Fernando, M. R. D., Jayatileke, J. M. S., Kagami, H., Mathavan, V., Matsueda, H., Motoyoshi, Y., Ogo, Y., Osanai, Y., Owada, M., Perera, L. R. K., Prame, K. B. N., Ranasinghe, N. S., Shiraishi, K., Vitanage, P. W. and Yoshida, M. (1990) Arrested charnockite formation in Sri Lanka: Field and petrographical evidence for low-pressure conditions. Proceedings of the NIPR Symposium on Antarctic Geosciences, No. 4, 213-230.

Hiroi, Y., Ogo, Y. and Nanba, K. (1994) Evidence for prograde metamorphic evolution of Sri Lankan pelitic granulites, and implications for the development of continental crust. Precambrian Research, 66: 245-263.

Hiroi, Y., Seneviratne, L. K., Motoyoshi, Y., Ellis, D. J. and Kondo, Y. (1995) Compositional zoning of garnet in pelitic granulite from Sri Lanka: Four major elements ( $\mathrm{Fe}, \mathrm{Mg}, \mathrm{Mn}, \mathrm{Ca}$ ) (in Japanese). Journal of Geological Society of Japan, 101, VII-VIII.

Hiroi, Y., Motoyoshi, Y., Ellis, D.J., Shiraishi, K. and Kondo, Y. (1997a) The significance of phosphorus zonation in garnet from high grade pelitic rocks: A new indicator of partial melting. The Antarctic region: Geological evolution and processes, Terra Antarctica Publication, Siena, 73-77.

Hiroi, Y., Motoyoshi, Y., Shiraishi, K. and Mathavan, V. (1997b) Local formation of hercynite-plagioclase symplectite after garnet and sillimanite in khondalite from Habarana, Sri Lanka: Mineral textures. Proceedings of the NIPR Symposium on Antarctic Geosciences, No. 10, 153-164.

Hiroi, Y., Yanagi, A., Kato, M., Kobayashi, T., Prame, B., Hokada, T., Satish-Kumar, M., Ishikawa, M., Adachi, T., Osanai, Y., Motoyoshi, Y. and Shiraishi, K. (2014) Supercooled melt inclusions in lower-crustal granulites as a consequence of rapid exhumation by channel flow. Gondwana Research, 25: 226-234. 
Hiroi, Y., Hokada, T., Kato, M., Yanagi, A., Adachi, T., Osanai, Y., Motoyoshi, Y and Shiraishi, K. (2019) Felsite-nanogranite inclusions and three $\mathrm{Al}_{2} \mathrm{SiO}_{5}$ polymorphs in the same garnet in ultrahigh-temperature granulites from Rundvågshetta, LützowHolm Complex, East Antarctica. Journal of Mineralogical and Petrological Sciences, 114: 60-78.

Hodges, K. V. and Crowley, P. D. (1985) Error estimation and empirical geothermobarometry for pelitic systems. American Mineralogist, 70: 702-709.

Holdaway, M.J., Mukhopadhyay, B., Dyar, M.D., Guidotti, C.V. and Dutrow, B.L. (1997) Garnet-biotite geothermometry revised: New Margules parameters and a natural specimen data set from Maine. American Mineralogist, 82: 582-595.

Hö1zl, S., Kohler, H., Kröner, A., Jaeckel, P. and Liew, T. C. (1991) Geochronology of Sri Lanka basement. In: Kröner, A. (Eds.) The Crystalline Crust of Sri Lanka, Part 1. Summary of Research of the German- Sri Lankan Consortium. Geological Survey Department of Sri Lanka, Professional Paper 5, 237- 257.

Jamieson, R.A., Beaumont, C., Warren, C.J. and Nguyen, M.H. (2010) The Grenville Orogen explained? Applications and limitations of integrating numerical models with geological and geophysical data. Canadian Journal of Earth Sciences, 47: 517-539.

Jamieson, R.A. and Beaumont, C. (2011) Coeval thrusting and extension during lower crustal ductile flow - implications for exhumation of high-grade metamorphic rocks. Journal of Metamorphic Geology, 29: 33-51.

Kehelpannala, K.V.W. (1997) Deformation of a high-grade Gondwana fragment, Sri Lanka. Gondwana Research, 1: 47-68.

Kehelpannala, K.V.W. (1999) Shear-zone controlled arrested charnockitization, retrogression and metasomatism of highgrade rocks. Gondwana Research, 2: 573577.

Kitano, I., Osanai, Y., Nakano, N., Adachi, T., and Fitzsimons, I C.W. (2018) Detrital zircon and igneous protolith ages of high-grade metamorphic rocks in the Highland and Wanni Complexes, Sri Lanka: Their geochronological correlation with southern India and East Antarctica. Journal of Asian Earth Sciences, 156: 122-144.

Kriegsman, L.M. and Schumacher, J.C. (1999) Petrology of sapphirine-bearing and associated granulites from central Sri Lanka. Journal of Petrology, 40: 1211-1239.

Kröner, A., Cooray, P. G. and Vitanage, P.W. (1991) Lithotectonic subdivision of the Precambrian basement in Sri Lanka. In: Kröner, A. (Eds.) The Crystalline Crust of Sri Lanka, Part 1. Summary of Research of the German- Sri Lankan Consortium. Geological Survey Department of Sri Lanka, Professional Paper 5, 5-21.

Kröner, A., Rojas-Agramonte, Y., Kehelpannala, K.V.W., Zack, T., Hegner, E., Geng, H. Y., Wong, J. and Barth, M. (2013) Age, Nd-Hf isotopes, and geochemistry of the Vijayan Complex of eastern and southern Sri Lanka: a Grenville-age magmatic arc of unknown derivation. Precambrian Research, 234: 288-321.

Lofgren, G.E. (1974) An experimental study of plagioclase crystal morphology: Isothermal crystallization. American Journal of Science, 274: 243-273.

London, D. (2008) Pegmatites. Canadian Mineralogist, Special Publication 10, 347 pp.

MacLellan, H.E. and Trembath, L.T. (1991) The role of quartz crystallization in the development and preservation of igneous texture in granitic rocks: Experimental evidence at $1 \mathrm{kbar}$. American Mineralogist, 76: 1291-1305.

Maneta, V. and Baker, D. R. (2014) Exploring the effect of lithium on pegmatite textures: An experimental study. American Mineralogist, 99: 1383-1403.

Manthilake, M.A.G.M., Sawada, Y. and Sakai, S. (2008) Genesis and evolution of Eppawala carbonatites, Sri Lanka. Journal of Asian Earth Sciences, 32: 66-75.

Mathavan, V., Prame, W.K.B.N. and Cooray, P. G. (1999) Geology of the high grade Proterozoic terrains of Sri Lanka and the assembly of Gondwana: an update on recent developments. Gondwana Research, 2: 237-250.

Milisenda, C.C., Liew, T. C., Hoffman, A. W. and Kröner, A. (1988) Isotopic mapping of age provinces in Precambrian high-grade terrains: Sri Lanka. Journal of Geology, 96: 608-615.

Milisenda, C. C., Liew, T. C., Hofmann, A. W. and Köhler, H. (1994) Nd isotopic mapping of the Sri Lankan basement: update, and additional constraints from $\mathrm{Sr}$ isotopes. In: Kröner, A. (Eds.), Tectonic, Metamorphic and Isotopic Evolution of Deep Crustal 
Rocks, With Special Emphasis on Sri Lanka. Precambrian Research, 66: 95-110.

Ogo, Y., Hiroi, Y., Prame, K.B.N. and Motoyoshi, Y. (1992) A new insight of possible correlation between the LützowHolm Bay granulites (East Antarctica) and the Sri Lankan granulites. In: Y. Yoshida (ed.), Recent Progress in Antarctic Earth Science, Terra Scientific Publishing Company, Tokyo, 75-86.

Osanai, Y. (1989) A preliminary report on sapphirine/kornerupine granulite from Highland Series, Sri Lanka, (Extended abstract). In: Seminar on Recent Advantages in Precambrian Geology of Sri Lanka, IFS Kandy, Sri Lanka.

Osanai, Y., Sajeev, K., Nakano, N., Kitano, I., Kehelpannala, W.K., Kato, R., Adachi, T. and Malaviarachchi, S.P. (2016a) UHT granulites of the Highland Complex, Sri Lanka I: geological and petrological background. Journal of Mineralogical and Petrological Sciences, 111: 145-156.

Osanai, Y., Sajeev, K., Nakano, N., Kitano, I., Kehelpannala, K.V.W., Kato, R., Adachi, T. and Malaviarachchi, S.P.K. (2016b) UHT granulites from Highland Complex, Sri Lanka II: Geochronological constraints and implications on Gondwana correlation. Journal of Mineralogical and Petrological Sciences, 111: 157-169.

Perchuk, L.L., Safonov, O.G., Gerya, T.V., Fu, B. and Harlov, D.E. (2000) Mobility of components in metasomatic transformation and melting of gneisses: an example from Sri Lanka. Contributions to Mineralogy and Petrology, 140: 212-232.

Perera, L.R.K. (1984) Co-existing cordieritealmandine - a key to the metamorphic history of Sri Lanka. Precambrian Research, 25: 349-364.

Perkins D. III and Chipera S. J. (1985) Garnetorthopyroxene-plagioclase-quartz barometry: refinement and application to the English River subprovince and the Minnesota River valley. Contributions to Mineralogy and Petrology, 89: 69-80.

Pohl, J.G. Emmermann, R. (1991) Chemical composition of the Sri Lanka Precambrian Basement. In: A. Kröner (Eds.) The Crystalline Crust of Sri Lanka, Part 1. Geological Survey Department of Sri Lanka. Professional. Paper 5, 94-123.

Prame, W.K.B.N. (1991) Petrology of the Kataragama Complex, Sri Lanka: evidence for high P-T granulite facies metamorphism and subsequent isobaric cooling. In: Kröner, A. (Eds.) The Crystalline Crust of Sri Lanka, Part 1. Summary of Research of the GermanSri Lankan Consortium. Geological Survey Department of Sri Lanka, Professional Paper 5, 200-224.

Raase, R. and Schenk, V. (1994) Petrology of granulite facies metapelites of the Highland Complex, Sri Lanka: implications for metamorphic zonation and P-T path. Precambrian Research, 66: 265-294.

Ranaweera, L. V., Perera, L. R.K., and Hiroi, Y. (2007) Blue dumortierite from Habarana, Sri Lanka: Field occurrence and mineral chemistry. Journal of Geological Society of Sri Lanka, 12: 53-74.

Roskosz, M., Toplis, M. J. and Richet, P. (2005) Experimental determination of crystal growth rates in highly supercooled aluminosilicate liquids: Implications for rate-controlling processes. American Mineralogist, 90: 11461156.

Sajeev, K. and Osanai, Y. (2004) Ultrahightemperature metamorphism $\left(1150{ }^{\circ} \mathrm{C}, 12\right.$ kbar) and multi-stage evolution of $\mathrm{Mg}-\mathrm{Al}$ rich granulites from the central Highland Complex, Sri Lanka, Journal of Petrology, 45: 1821-1844.

Sajeev, K. and Osanai, Y. (2005) Thermal gradients in the Sri Lankan granulite terrane: a garnet-biotite thermometric approach. Journal of metamorphic Geology, 23: 383397.

Sajeev, K., Osanai, Y., Connolly, J. A. D., Suzuki, S., Ishioka, J., Kagami, H., Rino, S. (2007) Extreme crustal metamorphism during a Neoproterozoic event in Sri Lanka, A study of dry mafic granulites, Journal of Geology, 115: 563-582.

Santosh, M., Tsunogae, T., Malaviarachchi, S. P. K., Zhang, Z., Ding, H., Tang, L. and Dharmapriya, P. L. (2014) Neoproterozoic crustal evolution in Sri Lanka: insights from petrologic, geochemical and zircon $\mathrm{U}-\mathrm{Pb}$ and $\mathrm{Lu}-\mathrm{Hf}$ isotopic data and implications for Gondwana assembly. Precambrian Research, 255: 1-29.

Schumacher, R. and Faulhaber, S. (1994) Summary and discussion of P-T estimates from garnet-pyroxene-plagioclase-quartzbearing granulite-facies rocks from Sri Lanka. Precambrian Research, 66: 295-308.

Sirbescu, M.-L.C., Schmidt, C. Veksler, I. V., Whittington, A., and Wilke, M. (2017) Experimental crystallization of undercooled 
felsic liquids: Generation of pegmatitic texture. Journal of Petrology, 58: 539-568.

Spear, F.S. (1994) Metamorphic Phase Equilibria and Pressure-Temperature-Time Paths. Mineralogical Society of America Monograph 1, 799 p.

Sunagawa, I. (2005) Crystals. Growth, Morphology and Perfection. Cambridge University Press, 295 pp.

Swanson, S.E. and Fenn, P.M. (1986) Quartz crystallization in igneous rocks. American Mineralogist, 71: 331-342.

Tani, Y. and Yoshida, M. (1996) The structural evolution of the Arena Gneisses and its bearing on Proterozoic tectonics of Sri Lanka. Journal of Southeast Asian Earth Sciences, 14: 309-329.

Takamura, Y., Tsunogae, T., Santosh, M., Malaviarachchi, S.P.K. and Tsutsumi, Y. (2016) U-Pb geochronology of detrital zircon in Sri Lanka: implications for the regional correlation of Gondwana fragments. Precambrian Research, 281: 434-452.

Touret, J.L.R., Huizenga, J.M., Kehelpannala, K.V.W. and Piccolia, F. (2019) Vein-type graphite deposits in Sri Lanka: The ultimate fate of granulite fluids. Chemical Geology, 508: 167-181.

Vitanage, P.W. (1972) Post-Precambrian uplift and regional neotectonic movements in Ceylon. 24th International Geological Congress, Montreal, Section 3, 642-654.

Weerakoon, M.W.K., Miyazaki, T. Shuto, K. and Kagami, H. (2001) Rb-Sr and Sm-Nd geochronology of the Eppawala metamorphic rocks and carbonatite, Wanni Complex, Sri Lanka. Gondwana Research, 4: 409-420.

Whitney, D.L. and Evans, B.W. (2010) Abbreviations for names of rock-forming minerals. American Mineralogist, 95: 185187.

Willbold, M., Hegner, E., Kleinschrodt, R., Stosch, H.G., Kehelpannala, K.V.W. and Dulski, P. (2004) Geochemical evidence for a Neoproterozoic magmatic continental margin in Sri Lanka-relevance for the RodiniaGondwana supercontinental cycle. Precambrian Research, 130: 185-198.

Yoshida, M. and Santosh, M. (1994) A tectonic perspective of incipient charnockites in East Gondwana. Precambrian Research, 66: 379392. 